\title{
Molecular identification and characterization of Dalapon-2,2-dichloropropionate (2,2DCP)-degrading bacteria from a Rubber Estate Agricultural area
}

\author{
Wen-Yong Wong and Fahrul Huyop* \\ Department of Industrial Biotechnology, Faculty of Biosciences and Bioengineering, Universiti Teknologi Malaysia, \\ 81310 Johor Bahru, Malaysia. \\ Accepted 23 January, 2012
}

\begin{abstract}
The extensive use of herbicides in agricultural area over the past years resulted in environmental pollution. A total of 4 potential bacterial strains were isolated from the rubber estate using minimal media containing 2, 2-dichloropropionate (2, 2-DCP) as sole source of carbon and energy. The $16 \mathrm{~S}$ rDNA analysis was carried out for genus identification study. Phylogenetic analysis suggested that strains D1, D6 and D9 were closely related with Enterobacter cloacae ATTC13047, whereas, strain Dw was closely related with Burkholderia sp. KU-25 with distance values of 0.001 and 0.004 base substitutions per site, respectively. Since strains D1, D6 and D9 belong to the same genus, therefore, D9 and Dw were further analysed. The growth profiles of both D9 and Dw in minimal liquid medium containing 40, 20 and $10 \mathrm{mM}$ 2,2-DCP were studied. Strain Dw growth was approximately 3 times faster than D9. In conclusion, faster growth rate for strain Dw indicates the pragmatic application of the bacterial strains to degrade residual herbicide in the environment.
\end{abstract}

Key words: Pollutant degradation, herbicide, Enterobacter, Burkholderia, dehalogenase and halogenated compound.

\section{INTRODUCTION}

Halogenated compound were used extensively as herbicide. They are toxic, persistence and poorly degraded in the environment (Alexander, 1999; Rieger et al., 2002). Previous studies showed that halogenated hydrocarbon like insecticides and polychlorinated biphenyl (PCB) were detected as residues in human adipose tissue, serum, and milk. Accumulation of these chemicals may bring harm to the human body (Gyorkos et al., 1985). In previous study, several soil bacteria were isolated based on growth on herbicide Dalapon or 2,2dichloropropionate (2,2-DCP) (Slater et al., 1979; Macgregor, 1963; Burge, 1969; Berry et al., 1979; Jing et

*Corresponding author. E-mail: fzhutm@gmail.com. Tel: +607 5534556. Fax: +6075531112. al., 2008; Huyop et al., 2004).

2,2-DCP has three carbons, with two chloride atoms bind at the $\alpha-C$ position $\left(C_{\alpha}\right)$. 2,2-DCP or Dalapon was often marketed as sodium salt and used to control seasonal weeds and is moderately toxic to human (Figure 1). Extensive use of Dalapon may results in leaching of the herbicide into ground water and cause pollution since it was extremely water soluble (EPA, 1988; Christian and Thompson, 1990).

Dehalogenases are key enzymes in the metabolism of halo-alkanoate compounds. Hill et al. (1999) described systematic approach to amplify two different families of $\alpha$ halocarboxylic acid ( $\alpha-\mathrm{HA})$ dehalogenase genes of group I and group II. Group I dehalogenases were nonstereospecific, whereas group II showing stereospecific, dechlorinating only L- but not D-2-chloropropionic acid. However, only few organism that can degrade $\beta$ - 


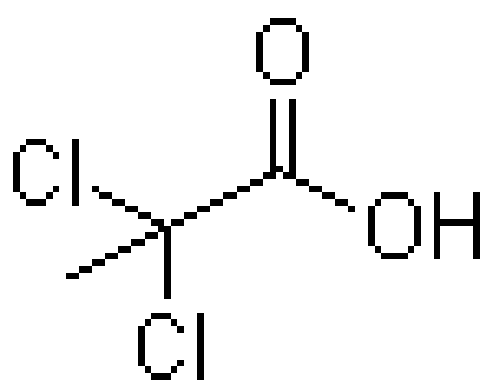

Figure 1. 2,2-dichloropropionic acid with formula molecule of $\mathrm{CH}_{3} \mathrm{CCl}_{2} \mathrm{CO}_{2} \mathrm{H}$.

halocarboxylic acid ( $\beta-\mathrm{HA})$ as reported by Mesri et al. (2009) and Yusn and Huyop (2009). Microorganisms are capable of evolving new enzymes, pathways and regulatory mechanisms for the degradation of almost all xenobiotic compounds due to their short life cycle (Timmis and Pieper, 1999). The only organism so far reported to make all three forms of dehalogenase is a Rhizobium sp. (Leigh et al., 1988).

Genomic DNA isolation, PCR amplification of the $16 \mathrm{~S}$ rDNA genes and direct determination of the PCRamplified 16S rDNA sequences were carried out by using methods that have been described previously (Hamid et al., 2010a,b). Therefore, current studies aimed on isolation and identification of bacterial species by $16 \mathrm{~S}$ rDNA gene analysis. The soil sample was taken from rubber estate in Melaka, Malaysia and we were particular interested in isolating new bacteria from this area due to its long time exposure to various kind of halogenated herbicide including Dalapon, Paraquat ${ }^{\mathrm{TM}}$ and 2,4Dichlorophenoxyacetic acid (2,4-D).

\section{MATERIALS AND METHODS}

\section{Growth media preparation}

The bacteria were grown aerobically in chloride-free minimal media as described earlier (Hareland et al., 1975) containing 2,2-DCP (between 10 to $20 \mathrm{mM}$ ) as the sole carbon and energy source. Carbon source-2,2-DCP was prepared as $1 \mathrm{M}$ stock solution. 2,2DCP $(1 \mathrm{M})$ was filter sterilized using $0.2 \mu \mathrm{m}$ nylon membrane filter and added to the sterilized minimal media at desired concentration.

\section{Bacteria isolation}

Soil sample $(5 \mathrm{~g})$ was mixed into minimal growth medium supplied with $5 \mathrm{mM} 2,2-\mathrm{DCP}$. The soil mixture was then incubated at $30^{\circ} \mathrm{C}$ on a rotary shaker set at $200 \mathrm{rpm}$ over night. The liquid culture from the growth medium was spread onto solid $10 \mathrm{mM}$ 2,2-DCP minimal medium. The potential bacteria were then selected after incubation over 4 to 5 days at $30^{\circ} \mathrm{C}$.
Alternatively, customized media was prepared as previously described by Fortin et al. (1998) and Greer et al. (1990). It was used to detect the release of chloride ions if the bacteria were able to utilize halogenated compound. The media contain $1 / 201 \mathrm{M}$ of $\mathrm{K}_{2} \mathrm{HPO}_{4} 3 \mathrm{H}_{2} \mathrm{O}, 1 / 201 \mathrm{M} \mathrm{NaH} \mathrm{PO}_{4} .2 \mathrm{H}_{2} \mathrm{O}, 50 \mathrm{mg} / \mathrm{L}$ yeast extract, 75 $\mathrm{mg} / \mathrm{L}$ bromothymol blue (pH 7.0) and $2 \mathrm{mM}$ 2,2-DCP. Bromothymol blue changes colour from green to yellow indicating the presence of $\mathrm{HCl}$ due to the chloride ion released.

\section{Growth measurement and assay for halide ion}

A $1.0 \mathrm{ml}$ of sample was taken from liquid growth medium aseptically at $6 \mathrm{~h}$ interval over $30 \mathrm{~h}$ growth period. The growth was measured at $A_{680 \mathrm{~nm}}$. Measurement of free halide released during the dehalogenation reaction was carried out by an adaptation of the method of Bergman and Sanik (1957). Sample $(1 \mathrm{ml})$ was added into $100 \mu \mathrm{l}$ of $0.25 \mathrm{M}$ ammonium ferric sulphate in $9 \mathrm{M}$ nitric acid and mixed thoroughly. To this was added $100 \mu \mathrm{l}$ mercuric thiocyanate-saturated ethanol and the solution was mixed by vortexing. The colour was allowed to develop for $10 \mathrm{~min}$ and measured at $A_{460 n m}$ in a Pye-Unicam SP1750 series spectrophotometer.

\section{DNA isolation and PCR of 16S rDNA}

DNA was prepared using Promega $\AA$ Wizard® Genomic DNA Purification Kit. The rehydrated DNA was stored in $-20^{\circ} \mathrm{C}$ freezer for further use. DNA concentration was estimated using Thermo NanoDrop ${ }^{\mathrm{TM}} 1000$ UV spectrophotometer where absorbance, $A_{260 \mathrm{~nm}}$ of 1.0 corresponds to $50 \mu \mathrm{g}$ of double stranded DNA per $\mathrm{ml}$.

PCR amplification of $16 \mathrm{~S}$ rDNA gene using universal primer suggested by Weisburg et al. (1991). PCR was carried out using $\mathrm{BIO}-\mathrm{RAD}^{\mathrm{TM}}$ MyCycler thermal cycler. The primers were fD1 (5' AGAGTTTGATCCTGGCTCAG - $\left.3^{\prime}\right)$ and rP1 (5'ACGGCTACCTTGTTACGACTT - 3'). The PCR protocol were denaturation at $94^{\circ} \mathrm{C}$ for $2 \mathrm{~min}$, followed by 30 cycles of $94^{\circ} \mathrm{C}$ for 1 min, $55^{\circ} \mathrm{C}$ for 1 minute and $72^{\circ} \mathrm{C}$ for $3 \mathrm{~min}$, and final elongation at $72^{\circ} \mathrm{C}$ for $5 \mathrm{~min}$. Amplicons were separated $(5 \mathrm{~V} / \mathrm{cm})$ by $1 \%$ agarose gel electrophoresis and stained using $6 \mathrm{mg} / \mathrm{mL}$ ethidium bromide before visualized under UV light.

\section{Partial dehalogenase gene amplification and analysis}

Putative dehalogenase gene was amplified using degenerative primers as suggested by Hill et al. (1999). The primers were dehll-F (5' - TGGCGVCARMRDCARCTBGARTA - 3') and dehll-R (5' TCSMADSBRTTBGASGANACRAA - 3'). Each PCR reaction (total volume $50 \mu \mathrm{l}$ ) contains $50 \mathrm{pmol}$ of each primer, $200 \mathrm{mM}$ deoxynucleoside triphosphates, $0.5 \mathrm{U}$ of $\mathrm{Taq}$ polymerase (Promega ${ }^{8}$ ), $50 \mathrm{mM} \mathrm{KCl}, 1.5 \mathrm{mM} \mathrm{MgCl} 2,10 \mathrm{mM}$ Tris- $\mathrm{HCl}$ (pH 9.0) and $200 \mathrm{ng}$ of DNA template. PCR was set as initial denaturation at $94^{\circ} \mathrm{C}$ for $10 \mathrm{~min}$ followed by 30 cycles of $94^{\circ} \mathrm{C}$ for $45 \mathrm{~s}, 55^{\circ} \mathrm{C}$ for 2 min, and $75^{\circ} \mathrm{C}$ for $45 \mathrm{~s}$, with a final elongation step at $75^{\circ} \mathrm{C}$ for 5 $\min$.

\section{Phylogenetic analysis of 16S rDNA genes}

The 16S rDNA sequences were compared with GenBank database using BLASTn method (Altschul et al., 1997). Sequence alignments of bacteria from different genus were constructed using profile 
Table 1. General characterization of bacteria D1, D6, D9 and Dw in minimal media supplied with $10 \mathrm{mM}$ 2,2-DCP.

\begin{tabular}{|c|c|c|c|c|c|c|c|c|c|}
\hline \multirow{2}{*}{ Isolate } & \multirow{2}{*}{ BLASTn (\% similarity) } & \multicolumn{6}{|c|}{ Bacterial colony morphology } & \multirow{2}{*}{$\begin{array}{l}\text { Size }(\mu \mathrm{m}) \text { Diameterl } \\
\text { length }\end{array}$} & \multirow{2}{*}[\mathrm{Cl}^{-}]{$\mu \mathrm{M}^{1}$} \\
\hline & & Age (days) & Colour & Size $(\mathrm{mm})$ & Shape & Margin & Surface & & \\
\hline $\mathrm{D} 1$ & E. cloacae ATCC 13047 (99\%) & 7 & White & $\sim 1.0$ & Circular & Curled & Raised & $0.6 \pm 0.03 / 2.4 \pm 0.3$ & 30 \\
\hline D6 & E. cloacae ATCC 13047 (99\%) & 7 & White & $\sim 1.0$ & Circular & Curled & Raised & $0.6 \pm 0.01 / 2.1 \pm 0.25$ & 30 \\
\hline Dw & Burkholderia sp. KU-25 (99\%) & 5 & Pale yellow & $\sim 1.0$ & Circular & Entire & Convex & $0.6 \pm 0.05 / 2.3 \pm 0.2$ & 100 \\
\hline
\end{tabular}

${ }^{1}$ Chloride ion release in growth substrate contained $1 \mathrm{mM}$ of 2,2-DCP.

alignment command of CLUSTAL-W of MEGA version 4 (Tamura et al., 2007). Evolutionary distances were calculated using p-distance (Jukes and Cantor, 1969) and phylogenetic trees with bootstrap test (500 replications) (Felsenstein, 1985) were constructed using NeighbourJoining method (Saitou and Nei, 1987). All sequences in FASTA format of related genus and species with highest similarity were obtained from National Center for Biotechnology Information (NCBI) GenBank.

\section{RESULTS}

\section{Isolation of pure bacteria able to utilize 2,2DCP}

Soil sample were obtained from Malacca rubber estate and several bacteria were isolated using minimal media. From 10 bacteria sample, only four isolates were consistently grown on $10 \mathrm{mM}$ 2,2DCP minimal medium. These isolates were designated as strain D1, D6, D9 and Dw.

\section{Analysis of 16S rRNA gene}

The bacteria were identified as Gram-negative as summarized in Table 1. The 16S rDNA PCR product was sequenced and analysed with NCBI accession number of JN986806 for D1/D6/D9 and JN986807 for Dw. The phylogenetic analysis indicates D1, D6 and D9 appeared to be in the same clad with Enterobacter cloacae ATTC13047, at $100 \%$ bootstrap value (Figure 2). Since D1, D6 and D9 were related, only D9 was further analysed. However, isolate Dw was related to Burkholderia with $99 \%$ similarity with Burkholderia sp. KU-25 (Figure 3).

\section{Halide ion assay and growth experiment}

Chloride ion assay was carried out, and maximum concentration of chloride ion [Cl] was shown in Table1. Growth profile of D9 and Dw were summarized in Table 2. However, no growth was detected in $80 \mathrm{mM}$ of 2,2DCP. The doubling time of Dw (3.96 h) was 3 times faster compared with D9 (11.44 h).

\section{Amplification of Group II dehalogenase gene}

Group II primers were used to perform PCR on all isolates to detect partial sequence of approximately $400 \mathrm{bp}$ of dehalogenase gene as described by Hill et al. (1999). However, there was no PCR band pattern on agarose gel electrophoresis suggesting D9 and Dw might possess new kind of dehalogenases.

\section{DISCUSSION}

The main objective of this study was to isolate new bacteria which could utilize and degrade Dalapon at high rate. There would be higher chance to isolate halogenated compound degrader in frequently polluted agricultural soil (Olaniran et al., 2004; Omori and Alexander, 1978), hence the soil sample was taken from heavily polluted of rubber estate.

Initially, 10 different isolates were obtained through sub-culturing by streak plate technique. Only D1, D6, D9 and Dw were selected for further investigation. Isolate D1, D6, D9 and Dw took shorter times (1 2 days) to form visible colonies, assuming they can efficiently utilized 2,2DCP (Dalapon) as sole carbon source, while other isolates took longer time ( $>5$ days) to form colonies or never form any colonies after subsequent sub-culturing steps. No colonies were formed from a media without 2,2DCP.

Growth profile for both D9 and Dw strains were established. Based on growth experiment, both bacteria were able to utilize 2,2DCP at faster rate, for example strain Dw. The 16S rDNA analysis suggested that D9 and Dw belongs to Enterobacter sp. and Burkholderia sp. with 99\% nucleic acid sequence identity, respectively. 


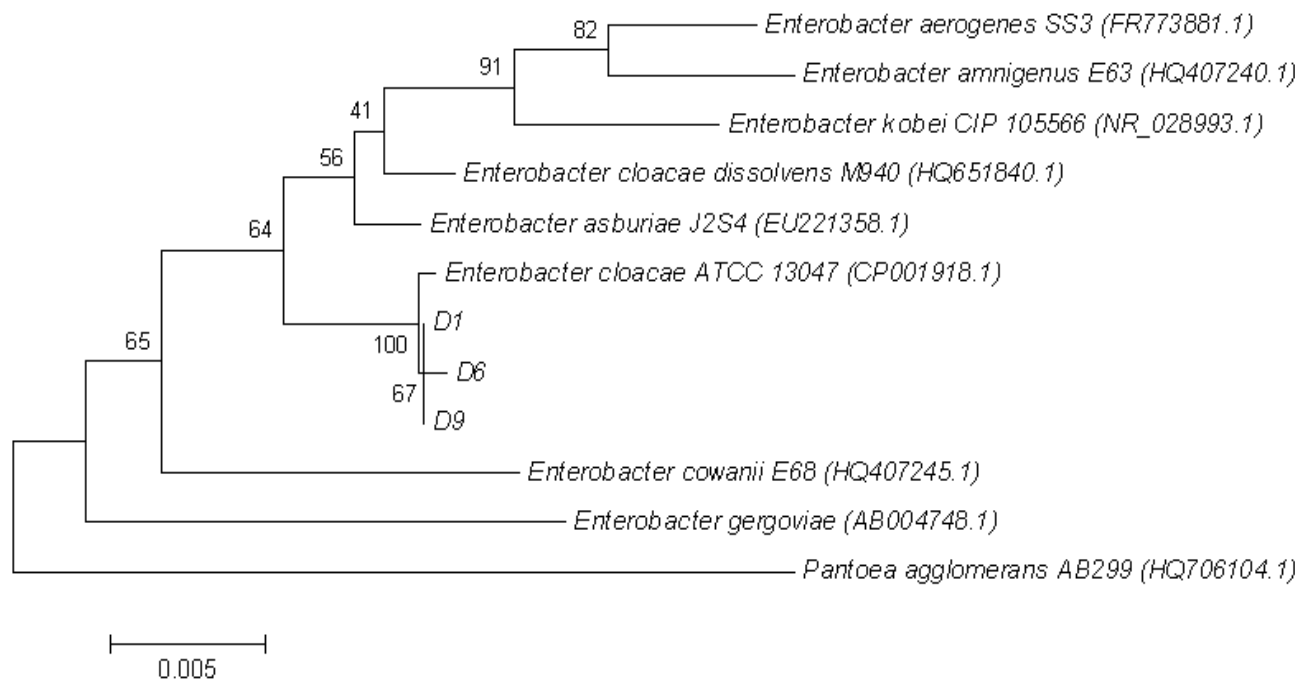

Figure 2. Neighbour joining tree of strains D1, D6 and D9 based on 16S rDNA gene sequences. The sequence of Pantoe agglomerans AB299-HQ706104.1 was used as the out group. Scale Bar 0.005 indicates sequence divergence.

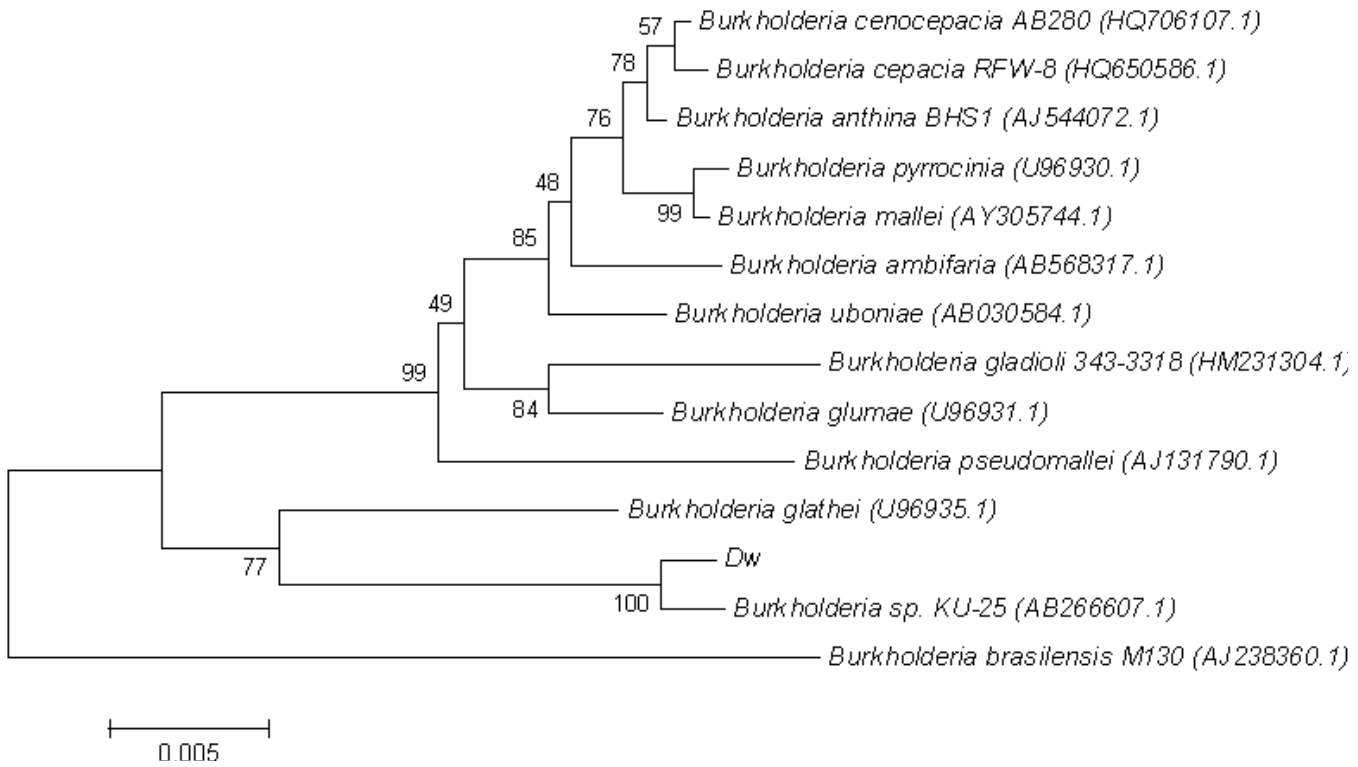

Figure 3. Neighbour joining tree of strain Dw based on 16S rDNA gene sequences. The sequence of $B$. brasilensisi M130-AJ238360.1 was used as the out group. Scale Bar 0.005 indicates sequence divergence.

Both strains could not withstand growth at $80 \mathrm{mM}$ 2,2DCP possibly due to the toxic effect of 2,2DCP. Slow growth was observed for D9 strain compared to Dw possibly due to inefficient substrate uptake system gene in D9 compared to Dw. Yu et al. (2007) suggested the uptake of halogenated compound into the bacterial cell was due to haloacid permease. Previous study identified haloalkanoic permease uptake system gene in the dehalogenase producing bacteria was essential for substrate uptake as proposed by Jing et al. (2010).

In previous investigation there was report on Burkholderia cepacia MBA4 which could degrade monobromoacetate(MBA), monochloroacetate(MCA), D, L2-chloropropionate(D,L2CP), and D, L-2-bromopropionate 
Table 2. Growth profile of bacteria D9 and Dw in triplicates on 10, 20, 40 and $80 \mathrm{mM}$ 2,2-DCP minimal medium.

\begin{tabular}{|c|c|c|c|c|c|c|c|c|c|}
\hline \multirow{3}{*}{ Isolate } & \multirow{3}{*}{ BLAST (\% similarity) } & \multicolumn{8}{|c|}{ 2,2-DCP concentration } \\
\hline & & \multicolumn{2}{|c|}{$10 \mathrm{mM}$} & \multicolumn{2}{|c|}{$20 \mathrm{mM}$} & \multicolumn{2}{|c|}{$40 \mathrm{mM}$} & \multicolumn{2}{|c|}{$80 \mathrm{mM}$} \\
\hline & & M.A. ${ }^{1}$ & D.T. $^{2}$ & M.A. & D.T. & M.A. & D.T. & M.A. & D.T. \\
\hline D9 & Enterobacter cloacae ATCC 13047 (99\%) & $0.48 \pm 0.001$ & 11.59 & $0.15 \pm 0.001$ & 12.24 & $0.28 \pm 0.005$ & 11.44 & $\mathrm{NG}^{3}$ & $\mathrm{NG}^{3}$ \\
\hline Dw & Burkholderia sp. KU-25 (99\%) & $0.21 \pm 0.003$ & 7.48 & $0.34 \pm 0.002$ & 06.16 & $0.66 \pm 0.001$ & 6.96 & $\mathrm{NG}^{3}$ & $\mathrm{NG}^{3}$ \\
\hline
\end{tabular}

${ }^{1}$ Maximum absorbance at $\mathrm{A}_{600 \mathrm{~nm} .}{ }^{2}$ Doubling time (hours). ${ }^{3} \mathrm{NG}$ : No growth.
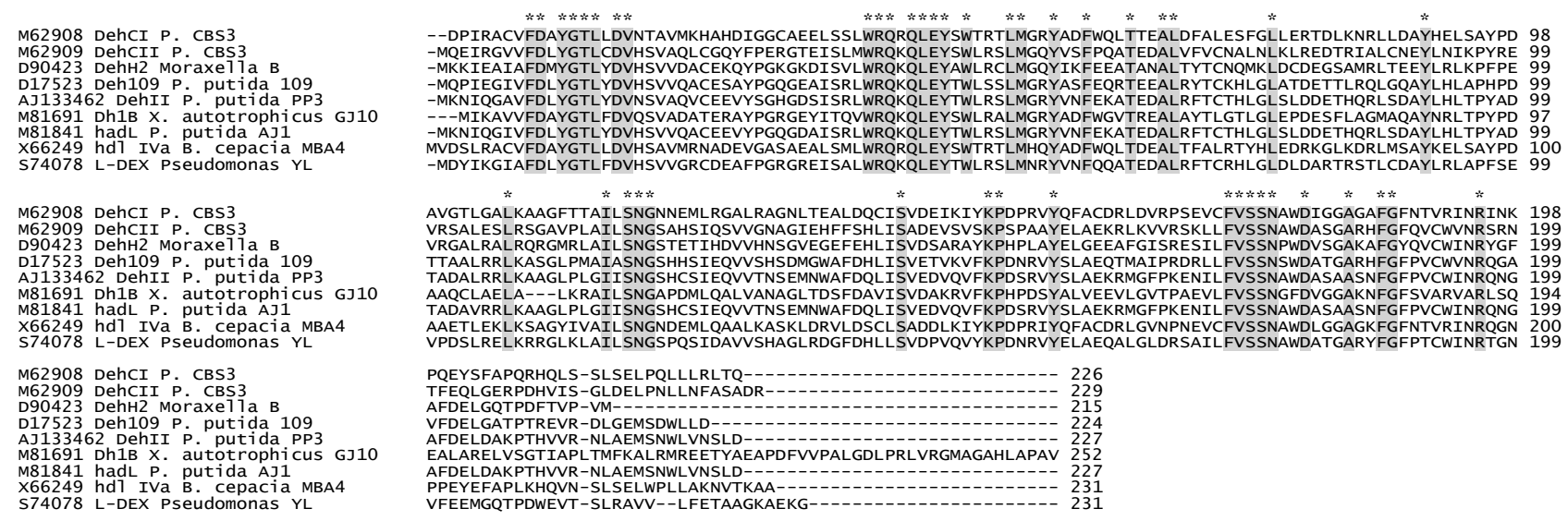

Figure 4. Conserve region (shaded) of group II $\alpha$-haloacid dehalogenase ( $\alpha \mathrm{HA})$. The primers were designed based on these conserved residues.

(D,L2BP) (Tsang and Sam, 1999). The dehalogenase enzyme produced by $B$. cepacia MBA4 is a dimeric with $45 \mathrm{kDa}$ protein designated as hdllVa (Murdiyatmo et al., 1992).

This study is the first reported case that Enterobacter $\mathrm{sp}$. could degrade halogenated compound like 2,2DCP. E. cloacae is a rod-shaped, Gramnegative bacterium from the Enterobacteriaceae family (Nishijima, 1999). This bacterium is always associated with urinary and respiratory tract infections (Barnes et al., 2003). In addition, other study reported that some Enterobacter sp. involved in degradation of complex halogenated compound like monochlorobiphenyls and dichlorobiphenyls as sole sources of carbon and energy (Adebusoye et al., 2007).

Several attempts were made to amplify Group II dehalogenase gene from D9 and Dw. But it was unsuccessful possibly due to the dehalogenase(s) of the isolate is evolutionary unrelated to Group II halidohydrolase. Alternatively, dehalogenase in D9 and Dw themselves might belongs to new kind of dehalogenases. The degenerate primers used were based on the conserve region of several amino acids as guideline for primer design as demonstrated by Nardi-Dei et al. (1997) (Figure 4). The small area of conserve region might or might 
not necessary shared by other novel dehalogenases. Some dehalogenase gene such as dehH1 from Moraxella sp. strain B (Kawasaki et al., 1992) and dehll from Rhizobium sp. NHG3 (Higgins et al., 2005) could not be amplified using Group I or II dehalogenase primers during $\mathrm{PCR}$ reaction.

In conclusion, the isolation of enteric bacteria from soil with a special ability to utilize 2,2DCP as sole source of carbon and energy suggests dehalogenase genes are well distributed across microbial genera. High growth rate of bacterium Dw indicates the pragmatic application of the bacterial strains to degrade residual Dalapon or $2,2 \mathrm{DCP}$ in the environment. The discovery of new microbes with new kind of dehalogenases is very important for future enzyme study.

\section{ACKNOWLEDGEMENTS}

Authors thank University Teknologi Malaysia- for financial award of GUP Vot No. QJ130000.7135.00H34- MOHE and ZAMALAH-UTM grants.

\section{REFERENCES}

Adebusoye SA, Picardial FW, Ilori MO, Amund OO, Fuqua C, Grindle N (2007). Aerobic degradation of di- and trichlorobenzenes by two bacteria isolated from polluted tropical soils. Chemosphere. 66: 19391946.

Alexander M (1999). Biodegradation and Bioremediation. $2^{\text {nd }}$ edition, London Academic Press, pp. 393-394.

Altschul SF, Madden TL, Schaffer AA, Zhang J, Zhang Z, MillerW, Lipman DJ (1997). Gapped BLAST and PSI-BLAST: A new generation of protein database search programs. Nucleic Acid Res., 25(17): 3389-3402.

Barnes BJ, Wiederhold NP, Micek ST, Polish LB, Ritchie DJ (2003). Enterobacter cloacae ventriculitis successfully treated with cefepime and gentamicin: Case report and review of the literature. Pharmacotherapy, 23(4): 537-542.

Bergman JG, Sanik J (1957). Determination of Trace Amounts of Chlorine in Naphtha. Ana. Chem., 29: 241-243.

Berry EKM, Allison N, Skinner AJ (1979). Degradation of the Selective Herbicide 2,2-Dichloropropionate (Dalapon) by a Soil Bacterium. J. Gen. Microb., 110: 39-45.

Burge WD (1969). Populations Of Dalapon-Decomposing Bacteria In Soil As Influenced By Additions Of Dalapon Or Other Carbon Sources. Am. Soc. Microb., App. Microb., 17(4): 545-550.

Christian FA, Thompson JA (1990). Sublethal Effects of 2,2Dichloropropionic Acid (Dalapon) on Fossariacubensis, Intermediate Host of the Liver Fluke, Fasciola hepatic. Bull. Environ. Contam.Toxicol., 45: 343-349.

EPA: Environmental Protection Agency, U. S. A. (1988). Health Advisory Summary: Dalapon. Office of Drinking Water, Washington, DC: pp. 6-43.

Felsenstein J (1985). Confidence-limits on phylogenies - An approach using the bootstrap. Evolution., 39: 783-791.

Fortin N, Fulthorpe RR, Allen DG, Greer CW (1998). Molecular analysis of bacterial isolates and total community DNA from kraft pulp mill effluent treatment system. Can. J. Microb., 44(6): 537.

Greer CW, Hawari J, Samson R (1990). Influence of environmental factors on 2,4-dichlorophenoxyacetic acid degradation by
Pseudomonas cepacia isolated from peat. Arch. Microb., 154: 317-322.

Gyorkos J, Denomme MA, Leece B, Homonko K, Valli V, Safe SF (1985). Reconstituted halogenated hydrocarbon pesticide and pollutant mixtures found in human tissues: Effects on the immature male Wistar rat after short-term exposure. Can. J. Physio. Pharmaco., 63(1): 36-43.

Hamid AAA, Hamdan S, Ariffin SH, Huyop F (2010a). Molecular prediction of dehalogenase producing microorganism using $16 \mathrm{~S}$ rDNA analysis of 2,2-dichloropropionic acid (Dalapon) degrading bacterium isolated from volcanic soil. J. Biol. Sci., 10(3): 190-199.

Hamid AAA, Hamdan S, Pakingking R, Huyop F (2010b). Identification of Pseudomonas strain S3 based on small subunit ribosomal RNA sequences. Biotechnol., 9(1): 33-40.

Hareland WA, Crawford RL, Chapman PJ, Dagley S (1975). Metabolic Function and Properties of 4-Hydroxyphenyl-Acetic Acid 1Hydroxylase from Pseudomonas acidovorans. J. Bacteriol., 121: 272285

Hill KE, Marchesi JR, Weightman AJ (1999). Investigation of two evolutionarily unrelated halocarboxylic acid dehalogenase gene families. J. Bacteriol., 181(8): 2535-2547.

Higgins TP, Hope SJ, Effendi AJ, Dawson S, Dancer BN (2005). Biochemical and molecular characterisation of the 2,3-dichloro-1propanol dehalogenase and stereospecific haloalkanoic dehalogenases from a versatile Agrobacterium. Biodegradation, 16(5): 485-492.

Huyop F, Tan YY, Ismail M, Wahab RAB, Cooper RA (2004). Overexpression and characterisation of non-stereospecific haloacid Dehalogenase E (DehE) of Rhizobium sp. Asia Pac. J. Mol. Bio. Biotech.,12: 15-20.

Jing NH, Mohd Taha A, Pakingking RV Jr, Wahab R Ab, Huyop F (2008). Dehalogenase from Methylobacterium sp. HJ1 Induced by the Herbicide 2,2-Dichloropropionate (Dalapon). Afri. J. Microb. Res. 2: 032-036. Jing NH, Wahab R Ab, Hamdan S, Huyop F (2010) Cloning and DNA sequence analysis of the haloalkanoic permease uptake gene from Rhizobium sp. RC1. Biotechnol., 9(3): 319-325.

Jukes TH, Cantor CR, (1969). Evolution of protein molecules. In: Munro, H. N. (Ed.), Mammalian Protein Metabolism. Academic Press, pp. 21-132.

Kawasaki H, Tsuda K, Matsushita I, Tonomura K (1992). Lack of homology between 2 haloacetate dehalogenase genes encoded on a plasmid from Moraxella sp. strain B. J. Gen. Microb.,138: 1317-1323.

Leigh JA, Skinner AJ, Cooper RA (1988) Partial purification, stereospecificity and stoichiometry of three dehalogenases from a Rhizobium species, FEMS Microbiol. Lett., 49: 353-356.

Macgregor AN (1963). The Decomposition of Dichloropropionate by Soil Microorganisms. J. Gen. Microb., 30: 497-501.

Mesri S, Wahab RA, Huyop F (2009). Degradation of 3-Chloropropionic Acid (3CP) by Pseudomonas sp. B6P Isolated from a Rice Paddy Field. Ann. Microb., 59(3): 447-451.

Murdiyatmo U, Asmara W, Tsang JSH, Baines AJ, Bull AT, Hardman DJ (1992). Molecular biology of the 2-haloacid halidohydrolase IVa from Pseudomonas cepacia MBA4. Biochem. J., 284: 87-93.

Nardi-Dei V, Kurihara T, Park C, Esaki N, Soda K (1997). Bacterial DL2-haloacid dehalogenase from Pseudomonas sp. strain 113: Gene cloning and structural comparison with D- and L-2-haloacid dehalogenases. J. Bacteriol., 179: 4232-4238.

Nishijima KA (1999). Enterobacter cloacae. Crop Knowledge Master. (http://www. extento. hawaii. edu/Kbase/crop/Type/e_cloac. htm).

Olaniran AO, Pillay D, Pillay B (2004). Haloalkane and Haloacid Dehalogenases from Aerobic Bacterial Isolates Indigenous to Contaminated Sites in Africa Demonstrate Diverse Substrate Specificities. Chemosphere, 55: 27-33.

Omori T, Alexander M (1978). Bacterial Dehalogenation of Halogenated Alkanes and Fatty Acids. Appl. Environ. Microb., 35(5): 867-871.

Rieger PG, Meier HM, Gerle M, Vogt U, Groth T, Knackmuss HJ (2002). Xenobiotics In The Environment: Present and Future Strategies to Obviate The Problem of Biological Persistence. J. Biotech., 94: 101123. 
Saitou N, Nei M (1987). The Neighbor-Joining Method: A New Method for Reconstructing Phylogenetic Trees. Mol. Bio. Evol., 4: 406-425.

Slater JH, Lovatt D, Weightman AJ, Senior E, Bull AT (1979). The growth of Pseudomonas putida on chlorinated aliphatic acids and its dehalogenase activity. J. Gen. Microb., 114: 125-136.

Tamura K, Dudley J, Nei M, Kumar S (2007). MEGA4: Molecular Evolutionary Genetics Analysis (MEGA) software version 4.0. Mol. Bio. Evol., 24: 1596-1599.

Timmis KN, Pieper DH (1999). Bacteria Designed for Bioremediation. Trends in Biotech.,17: 201-204.

Tsang JHS, Sam LJ (1999). Cloning and Characterization of a Cryptic Haloacid Dehalogenase from Burkholderia cepacia MBA4. J. Bacteriol., 181(19): 6003-6009.
Weisburg WG, Barns SM, Pelletier DA, Lane DJ (1991). 16S ribosomal DNA amplification for phylogenetic study. J. Bacteriol., 173(2): 697703.

Yu M, Faan Y-W, Chung WYK, Tsang SH (2007). Isolation and characterization of a novel haloacid permease from Burkholderia cepacia MBA4. Appl. Environ. Microbiol., 73(15): 4874-4880.

Yusn TY, Huyop F (2009). Degradation of 3-Chloropropionic Acid by Escherichia coli JM109 Expressing Dehalogenase (deh) Gene used as Selection Marker. Biotech., 8(3): 385-388. 